\title{
Article
}

\section{Phonological Coding during Sentence Reading in Chinese Deaf Readers: An Eye- Tracking Study}

Yan, Guoli, Lan, Zebo, Wang, Yingchao and Benson, Valerie Available at http://clok.uclan.ac.uk/33528/

Yan, Guoli, Lan, Zebo, Wang, Yingchao and Benson, Valerie ORCID: 00000002-0351-4563 (2021) Phonological Coding during Sentence Reading in Chinese Deaf Readers: An Eye-Tracking Study. Scientific Studies of Reading, 25 (4). pp. 287-303. ISSN 1088-8438

It is advisable to refer to the publisher's version if you intend to cite from the work. http://dx.doi.org/10.1080/10888438.2020.1778000

For more information about UCLan's research in this area go to http://www.uclan.ac.uk/researchgroups/ and search for <name of research Group>.

For information about Research generally at UCLan please go to http://www.uclan.ac.uk/research/

All outputs in CLoK are protected by Intellectual Property Rights law, including Copyright law. Copyright, IPR and Moral Rights for the works on this site are retained by the individual authors and/or other copyright owners. Terms and conditions for use of this material are defined in the policies page.

\section{CLoK}

Central Lancashire online Knowledge www.clok.uclan.ac.uk

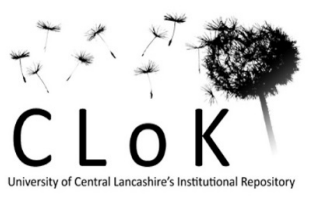


Scientific Studies of Reading

Running head: PHONOLOGICAL CODING IN CHINESE DEAF READERS

\section{Phonological Coding during Sentence Reading in Chinese Deaf}

\section{Readers: An Eye-Tracking Study}

3 Guoli Yan ${ }^{\mathrm{a}}$, Zebo Lan ${ }^{\mathrm{a}}$, Zhu Meng $^{\mathrm{a}}$, Yingchao Wang ${ }^{\mathrm{a}}$, \& Valerie Benson ${ }^{\mathrm{b} *}$

$4{ }^{a}$ Academy of Psychology and Behaviour, Tianjin Normal University, Tianjin, P. R.

5 China; ${ }^{b}$ School of Psychology, University of Central Lancashire, Preston, UK

6 *corresponding author: Valerie Benson, School of Psychology, University of Central

7 Lancashire, Preston, UK, PR12HE; Email: VBenson3@uclan.ac.uk.

8

9

10

11

12

13

14

15

16

17

18

19

20

21 
Scientific Studies of Reading

\section{Running head: PHONOLOGICAL CODING IN CHINESE DEAF READERS}

\section{Phonological Coding during Sentence Reading in Chinese Deaf}

2 Readers: An Eye-Tracking Study

Phonological coding plays an important role in reading for hearing students. Experimental findings regarding phonological coding in deaf readers are controversial, and whether deaf readers are able to use phonological coding remains unclear. In the current study we examined whether Chinese deaf students could use phonological coding during sentence reading. Deaf middle school students, chronological age-matched hearing students, and reading abilitymatched hearing students had their eye movements recorded as they read sentences containing correctly spelled characters, homophones, or unrelated characters. Both hearing groups had shorter total reading times on homophones than they did on unrelated characters. In contrast, no significant difference was found between homophones and unrelated characters for the deaf students. However, when the deaf group was divided into more-skilled and less-skilled readers according to their scores on reading fluency, the homophone advantage noted for the hearing controls was also observed for the more-skilled deaf students.

Keywords: deaf readers; sentence reading; phonological coding; eye movements

Word count: 5974

\section{Introduction}

Previous studies have found that many deaf individuals or hearing-impaired students experience difficulty in learning to read, and the literacy development of average deaf readers is delayed compared with their hearing peers (Kyle \& Cain, 2015; Wauters, van Bon, \& Tellings, 2006). It is a significant achievement for deaf students to be able to read at an age-appropriate level, but the majority fail to attain a level of literacy that enables them to cope with the daily demands of modern society (Harris \& Moreno, 2004). Investigating the cause of the reading difficulty in the deaf is thus very 
Scientific Studies of Reading

\section{Running head: PHONOLOGICAL CODING IN CHINESE DEAF READERS}

1 important. Moreover, attaining understanding of the nature of reading in the deaf would

2 be expected to contribute to theoretical models of reading (e.g. Mayberry, del Giudice,

3 \& Lieberman, 2011).

Since the main difference between deaf and hearing students is the lack of auditory experience, one plausible hypothesis for reading difficulties in deaf readers is

6 that they fail to develop a fully specified phonological representation of words

7 (Bélanger, Baum, \& Mayberry, 2012). In the present study we examined whether

8 Chinese deaf readers are able to use phonological coding during reading.

For hearing readers, phonological coding is critical for high reading achievement

(Perfetti \& Sandak, 2000). According to cognitive models of reading (Coltheart, Rastle,

11 Perry, Ziegler, \& Langdon, 2001; Ziegler \& Goswami, 2005), the route by which

12 readers access semantics may either be directly from orthography, or indirectly via

13 phonological mediation during reading. Regardless of which route is used for semantic access, a number of studies have supported that phonological coding plays an important role in the reading of hearing readers, even in logographic scripts like Chinese

16 (Grainger \& Ferrand, 1994; Lee, Rayner, \& Pollatsek,1999; Lukatela, Frost, \& Turvey, 1998; Tan \& Perfetti, 1998). A four-year longitudinal study examined the relationship between Chinese children's phonological skills and their success in reading (Ho \& Bryant, 1997). The results showed that prereading phonological skills strongly predicted children's reading performance two to three years later. deaf students have been controversial (Mayberry et al., 2011). One view suggests that

23 deaf readers could activate phonological coding during reading in the same way as hearing readers (Musselman, 2000; Transler \& Reitsma, 2005), and the difficulty of 
Scientific Studies of Reading

\section{Running head: PHONOLOGICAL CODING IN CHINESE DEAF READERS}

1 reading in deaf readers might be due to delayed reading development (Paul \& Lee,

2 2010). An opposing view (to the delayed reading development view) is that deaf readers

3 have little reliance on phonological coding (Fariña, Duñabeitia, \& Carreiras, 2017;

4 McQuarrie \& Parrila, 2009; Perea, Marcet, \& Vergara-Martinez, 2016), and instead

5 prefer to use different qualitative processes during reading (nonauditory channels, such

6 as visual lip reading, sign language; see Bélanger et al., 2012).

7 However, much of this research has used isolated word recognition tasks

8 (single/double-character word recognition task) or phonology judgment tasks. For

9 example, Friesen and Joanisse (2012) reported a study that required hearing and deaf

10 adults to perform lexical decisions on homophones and control words in the context of

11 either pseudoword foils (e.g., CLANE) or pseudohomophone foils (e.g., BRANE). Deaf

12 readers responded more slowly to homophones than to control words in the

13 pseudohomophone foil context, but not in the pseudoword foil context, whereas hearing

14 readers responded more slowly to homophones than to control words in both non-word

15 contexts. This finding suggests that deaf readers had activated phonological

16 representations, but these activations were either different from or not as detailed as the

17 representations activated in the hearing group. However, Fariña, Duñabeitia, and

18 Carreiras (2017) used a lexical decision task and found that hearing adults made a

19 higher percentage of errors when rejecting pseudohomophones compared to control

20 nonwords, whereas error rates for deaf adults were similar between pseudohomophones

21 and control nonwords, suggesting that the deaf adults did not activate phonological

22 coding in this study.

23 Importantly, the studies reported above that have employed isolated word

24 recognition tasks may not reflect on-line cognitive processing during natural reading, 
Scientific Studies of Reading

\section{Running head: PHONOLOGICAL CODING IN CHINESE DEAF READERS}

1 and as such any investigation of the roles of phonological skills in single word reading

2 cannot provide a full account of phonological processing in sentence or passage reading.

3 Little research to date has directly examined the phonological coding of deaf readers in

4 natural sentence reading (only three studies have investigated this in alphabetic

5 languages). Hanson, Goodell, and Perfetti (1991) used tongue twisters to test whether

6 deaf readers activated phonological coding in sentence reading. They found that both

7 deaf and hearing college students made more errors in their acceptability judgments on

8 tongue-twisters than they did on control sentences which indicated that deaf readers can

9 use phonological coding during reading.

10 Recently eye movement methodology has been adopted to investigate whether

11 deaf readers activate phonological coding during natural and silent sentence reading as

12 they read. The eye movement data are very informative as they allow us to understand

13 whether there are on-line processing differences between the deaf and hearing readers

14 during natural sentence reading. For example, Bélanger, Mayberry, and Rayner (2013)

15 used the boundary paradigm to explore adult deaf readers' processing of phonological

16 coding in parafoveal vision (the word next to the currently fixated word) during

17 sentence reading. They found no evidence for a parafoveal phonological preview

18 benefit in both skilled and less-skilled deaf readers, but hearing readers showed a

19 phonological preview benefit. In contrast, Blythe, Dickins, Kennedy, and Liversedge

20 (2018) adopted the same boundary paradigm and observed phonological coding from

21 parafoveal vision in deaf teenagers. In another study, Blythe et al. (2018) used the error

22 disruption paradigm to examine phonological coding from foveal vision (directly

23 fixated words) during sentence reading in the deaf teenagers. The results showed that 
Scientific Studies of Reading

\section{Running head: PHONOLOGICAL CODING IN CHINESE DEAF READERS}

1 deaf teenagers showed a pseudohomophone advantage, providing evidence for

2 phonological coding of fixated words during sentence reading in deaf teenagers.

The lack of consistency across previous findings in relation to phonological

4 coding in the deaf could be partially accounted for by many factors that include

5 individual differences, differences in task demands, and the transparency of the

6 language system, amongst others (Hirshorn, Dye, Hauser, Supalla, \& Bavelier, 2015;

7 McQuarrie \& Parrila, 2008).

In the present study we adopt an error disruption paradigm, which allows us to

9 examine the phonological processing of text during natural sentence reading. In the

10 error disruption paradigm, participants read each sentence with either a correctly spelled

11 word (e.g. He wore blue jeans), a homophone (e.g. He wore blew jeans) or a spelling

12 control word (e.g. He wore blow jeans) (Jared \& O'Donnell, 2017). The rationale is

13 that, substitutions (e.g., homophones), which preserve similar features with the correctly

14 spelled word, should be less disruptive to reading compared to unrelated spelling

15 control words, to the extent that readers rely on certain features (e.g. phonology) to aid

16 reading (Daneman \& Reingold, 1993). Studies using this paradigm have observed

17 phonological coding during sentence reading in hearing students (Blythe, Pagán, \&

18 Dodd, 2015; Jared, Ashby, Agauas, \& Levy, 2016; Rayner, Pollatsek, \& Binder, 1998),

19 and also in deaf readers (Blythe, Dickins, Kennedy, \& Liversedge, 2018) in western

20 populations.

Unlike alphabetic writing systems, Chinese is a writing system with deep

22 orthography, and the orthography-phonology mapping of Chinese characters is not

23 always consistent and regular (Zhou \& Marslen-Wilson, 2000). Two Chinese characters

24 with the same pronunciation can be completely different in orthography, for example, 
Scientific Studies of Reading

\section{Running head: PHONOLOGICAL CODING IN CHINESE DEAF READERS}

1 阳 (yang, the tone is second) and 洋 (yang, the tone is second). Thus, Chinese materials

2 offer a unique opportunity to eliminate the confound between grapheme and phoneme

3 associations in alphabetic languages. Feng, Miller, Shu, and Zhang (2001) have shown

4 that hearing Chinese college students take advantage of phonological features in reading

5 using the error disruption paradigm. Their findings suggest that phonological

6 information helps hearing readers to recover from disruptive effects of making errors.

7 The study of Yan, Pan, Bélanger, and Shu (2015), the first to investigate the

8 phonological coding of Chinese deaf readers (using a boundary paradigm) during

9 Chinese sentence reading, reported that more-skilled Chinese deaf readers were able to

10 process parafoveal phonological information. The current study adopts the error

11 disruption paradigm which offers the advantage of permitting an investigation of foveal

12 phonological processing during natural sentence reading in Chinese deaf readers.

13 In the current study, on the basis of previous studies with hearing participants,

14 (Feng et al., 2001; Zhou, Shu, Miller, \& Yan, 2017), both groups of hearing readers

15 (chronological age-matched (CA) and reading ability-matched (RA) hearing readers)

16 would be predicted to show shorter reading times on homophones than on spelling

17 control words (a homophone advantage), reflecting activation of phonological coding

18 during sentence reading. If deaf students fail to activate phonological coding during

19 sentence reading, an absence of a homophone advantage (shorter reading times on

20 homophones) would be predicted for the deaf group. 
Scientific Studies of Reading

\section{Running head: PHONOLOGICAL CODING IN CHINESE DEAF READERS}

\section{Method}

\section{Participants}

3 There were three participant groups, namely, deaf middle school students (DS);

4 chronological age-matched (CA) controls; and reading ability-matched (RA) controls,

5 with 34 participants in each group. The DS were severely to profoundly deaf (hearing

6 loss above $80 \mathrm{~dB}$ in their better ear) and all wore hearing aids. None had received a

7 cochlear implant. Deaf participants were born deaf or they became deaf before the age

8 of three, used Chinese sign language as their main language for communication, and

9 were aged from 13.7 to 20.0 years $(M=17.37, S D=1.74)$. Deaf participants were

10 educated in a school for the deaf, and they were all taught sign language from the age of

11 six years at school. All deaf participants were proficient in sign language and all were

12 learning to read written Chinese. The parents of the deaf participants all had normal

13 hearing.

14 All participants in CA and RA controls had normal hearing. The CA controls

15 were aged from 13.42 to 20.8 years $(M=16.86$ years, $S D=2.14)$ were matched to the

16 DS on chronological age $(t=-1.12, p>0.05)$. The RA controls were aged from 10.16 to

1711.72 years $(M=10.74, S D=0.34)$, and were matched to the DS on reading fluency,

18 reading comprehension and nonverbal IQ (see Table 1 for tests used and summary

19 scores). The reading fluency test requires readers to read and comprehend simple

20 sentences and to judge the contents as rapidly as possible within a three minute time

21 frame by ticking a box at the end of each sentence to indicate whether the information is

22 correct or incorrect (for example, 'the sun rises in the west'; Pan et al., 2011; Lei et al.,

23 2011). The number of characters marked with correct sentences within 3 minutes is

24 calculated as the dependent variable. For reading comprehension, participants were 
Scientific Studies of Reading

\section{Running head: PHONOLOGICAL CODING IN CHINESE DEAF READERS}

1 asked to answer multiple choice questions or subjective questions after reading a short

2 essay (Li, Wu, Zhou, Chen, \& Nguyen, 2016). Raven's Standard Progressive Matrices

3 were administered (Raven, Court, \& Raven, 1996) to measure nonverbal IQ.

\section{$5 \quad$ Material and Design}

6 A total of 45 two-character target words were created and embedded into sentence

7 frames. Two fourth grade teachers from Tianjin Primary School and two middle school

8 teachers from Tianjin Deaf School proofread the sentences and reported no unfamiliar

9 words for the students. The first character of each target word was replaced by either an

10 identical character (e.g., 阳光, the pronunciation is Yang, the tone is second), a

11 homophone (the homophone share the pronunciation with the identical character, e.g.,

12 洋光, the pronunciation is Yang, the tone is second) or an unrelated substitution (the

13 unrelated substitution was different from the identical character in spelling,

14 pronunciation and meaning, e.g., 绝光, the pronunciation is Jue, the tone is second).

15 Table 2 shows a summary of the linguistic property measures that the three types of

16 substitutions were matched on: (1) character frequencies, $F(2,118)=0.49, p>0.05$,

17 (2) visual complexity indexed by number of strokes, $F(2,118)=1.06, p>0.05$.

19 Rating Studies: A total of 40 fourth graders were invited to conduct two norming studies to ensure that the sentences were neutral. Firstly, the predictability of the targets

21 was assessed based on sentence constraint ratings. Half of the participants were given

22 the sentence context with a blank space in the location of the target word and were

23 asked to fill in the word that best completed the sentence. The mean score of the 
Scientific Studies of Reading

\section{Running head: PHONOLOGICAL CODING IN CHINESE DEAF READERS}

1 sentences was 5\% $(S D=0.09)$, indicating that all target words in the sentences were

2 low on predictability. Secondly, sentence difficulty was assessed on a five-point scale

3 (e.g., a score of " 5 " was "very difficult" to understand). Half of the participants were

4 presented with complete sentences with the correct target word and asked to rate each

5 one. The mean score of the sentences was $1.24(S D=0.24)$, indicating that all sentences

6 were appropriate given the reading level of the participants.

7 The experimental sentences had a length of 14 to 17 characters $(M=15.15, S D=$

8 1.00). The target words consisted of two characters which never appeared among the

9 first four or the last four characters. Each sentence was presented only once to each

10 participant, with all of the conditions counterbalanced. Each participant read 45

11 sentences (15 per condition), which were randomly presented during the experiment.

12 The sentences used in the experiment are presented in full in Appendices 1.

\section{Apparatus}

14 An EyeLink 2000 (SR Research Ltd.) eye tracker was used to record the readers' eye

15 movements, and the sampling rate was $1000 \mathrm{~Hz}$. All calibrations and recordings were

16 based on the right eye only. Single-line sentences were displayed on a ViewSonic

17 G220f 21-inch CRT monitor (refresh rate, $120 \mathrm{~Hz}$; resolution, $1024 \times 768$ pixels) at a

18 viewing distance of $65 \mathrm{~cm}$. Characters were displayed using the font Song 28 and each

19 character subsumed $0.9^{\circ}$ of visual angle.

\section{Procedure}

21 Participants were seated comfortably, and then a three-point horizontal calibration and validation procedure was conducted. If the individual mean validation error or the error

23 for any one of the points was greater than $0.2^{\circ}$, then the procedure was repeated. The 
Scientific Studies of Reading

\section{Running head: PHONOLOGICAL CODING IN CHINESE DEAF READERS}

1 first nine trials were practice trials with three easy yes-no questions related to the

2 meaning of the sentences. Participants were presented with a single sentence at a time

3 and were instructed to read the sentences silently, and to press a button on the gamepad

4 once they had finished reading. On one-third of the trials, the sentence was followed by

5 a comprehension question, to which participants responded yes or no using a button on

6 the gamepad. Participants were informed that some of the words might be misspelled,

7 but they should simply do their best to understand the sentence. The overall

8 experimental session lasted for approximately 15 minutes.

\section{$9 \quad$ Data analysis}

10 Following convention (Bai, Yan, Liversedge, Zang, \& Rayner, 2008), a data reduction

11 procedure combined short fixations (shorter than $40 \mathrm{~ms}$ ) with nearby fixations, after

12 which fixations shorter than $80 \mathrm{~ms}$ or longer than $1200 \mathrm{~ms}$ were removed. Trials, in

13 which sentences received less than three fixations were deleted (affecting approximately

$142.3 \%$ ), as well as trials, in which scores were more than three SD's from each

15 participant's mean (FFD:1.4\%; GD: 1.8\%; RP: 2.0\%; TT: 1.2\%). Similar to previous

16 studies in Chinese (e.g. Zhou et al., 2017), data analyses were performed within two-

17 character word regions for the target words.

18 Three early-stage processing and two late-stage processing eye movement

19 measures, defined according to Jared \& O’Donnell (2017) and Friesen, Whitford,

20 Titone, \& Jared (2020), were examined. Early-stage measures reflect early lexical

21 identification of a word, and include First Fixation Duration (FFD) which is the

22 duration of the first fixation on a word regardless of how many other fixations were

23 made, Gaze Duration (GD) which is the sum of all fixations on a word prior to moving

24 on to a different word, including refixations, and Regression out, which is the 
Scientific Studies of Reading

\section{Running head: PHONOLOGICAL CODING IN CHINESE DEAF READERS}

1 probability of regressing out of a word to an earlier word. Late-stage measures reflect

2 later integration processing of the sentences and later lexical identification, and include

3 Regression Path Time (RP) which is the sum of all fixation durations on a region from

4 first entering the region until going past that region, and Total Reading Time (TT)

5 which is the sum of all fixations on a word throughout the duration of the trial.

6 Although skipping rates were also examined, there were no significant differences

7 between the homophones and unrelated words $(b=0.05, S E=0.11, z=0.42)$; thus,

8 detailed analyses are not reported. Each measure is reported for the analyses of target

9 words in the sentences.

If phonological coding occurs in the early lexical identification stage, we should

11 observe that participants' FFD on homophones are shorter than FFD on unrelated

12 words, that participants' GD on homophones are shorter than GD on unrelated words,

13 and that participants produce fewer regression out for homophones compared to

14 unrelated words. If phonological coding is activated during sentence integration

15 processing, we should observe that participants produce less RP for homophones

16 compared to unrelated words, and if phonological coding occurs in the later lexical

17 identification stage, we should observe that participants' TT on homophones are shorter

18 than TT on unrelated words.

19 Analyses were performed with liner-mixed effects models (Bates, Maechler, \&

20 Dai, 2009) within the R environment (R Development Core Team, 2012). For each

21 variable, fixed effects included Group and Word Type, and random effects included

22 random intercepts for participants and items, random slopes for Word Type across

23 participants, and random slopes for Word Type and Group across items. If the initial

24 model failed to converge then the random structure was incrementally trimmed, 
Scientific Studies of Reading

\section{Running head: PHONOLOGICAL CODING IN CHINESE DEAF READERS}

1 beginning with the items level. The model was run on log-transformed reading time.

2 Logistic generalized linear mixed models (GLMMs) were used for the regression data

3 and skip data. We report regression coefficients $(b)$, standard errors $(S E)$, and t values or

$4 \mathrm{z}$ values ( $t$ or $z=b / S E)$. A two-tailed criterion $(|t|$ or $|z| \geq 1.96)$ was used to determine

5 significance. The error disruption paradigm assumes that if readers activate the

6 meanings of words using phonological coding, then homophones should produce

7 shorter reading times compared to reading times on unrelated words. So, we mainly

8 focus on the differences in reading times (for all eye movement measures) between

9 homophones and unrelated words.

\section{Results}

\section{Deaf students compared with control groups}

12 Four participants from the DS, three from the RA controls, and one from the CA

13 controls were excluded from the data analysis because their response accuracy for

14 comprehension questions was below 70\%. The accuracy of the comprehension

15 questions by the participants included in the analyses was 90\% (RA controls), $89 \%$

16 (DS) and 95\% (CA controls). A one-way analysis of variance (ANOVA) showed that

17 the difference in reading accuracy of the three groups was significant $[F(2,93)=5.78$,

$18 p<0.05]$. Post-hoc tests found that the RA controls had a significantly lower reading

19 accuracy than the CA students $(p<0.05)$, and the deaf students' reading accuracy was

20 lower than the CA controls $(p<0.05)$. In general, all three groups had high accuracy

21 demonstrating and understanding of the meaning of the sentences.

22 Means for each eye movement measure, broken down by participant group and

23 experimental condition are shown in Table 3. We ran the model with group (RA, DS, 
Scientific Studies of Reading

\section{Running head: PHONOLOGICAL CODING IN CHINESE DEAF READERS}

1 CA), and word type (correctly spelled words, homophones, unrelated words) as fixed

2 factors. The results of this model for the eye movement measures are shown in Table 4.

3

4

$5 \quad$ Early-stage measures

6 There was no significant difference between homophones and unrelated words in FFD

7 and GD, and no interaction between group and word type (homophones vs. unrelated

8

9
--TABLE 3-

--TABLE 4- words) in FFD and GD, indicating that neither of the three groups showed an early

processing homophone advantage. In the group main effects, the difference was not significant for group in FFD. The RA controls' GD was significantly longer than the DS' GD. However, there was no significant difference between the DS and CA controls in GD.

A significant effect of word type (homophones vs. unrelated words) was found in regression out. Fewer regressions out occurred for homophones than for control words. The group (RA vs. DS) and word type (homophones vs. unrelated words) interaction was marginal significant, but the group (DS vs. CA) and word type (homophones vs. unrelated words) interaction was not significant. For the DS, there was no significant homophone advantage $(b=-0.05, S E=0.22, z=-0.22)$. For the RA controls, there was a significant homophone advantage $(b=-0.52, S E=0.16, z=-3.34)$, fewer regressions out occurred for homophones than for control words. In the group main effects, fewer regressions out occurred for the DS than for both controls. 
Scientific Studies of Reading

\section{Running head: PHONOLOGICAL CODING IN CHINESE DEAF READERS}

$1 \quad$ Late-stage measures

2 A significant difference between homophones and unrelated words was observed in RP

3 and TT. Homophones were fixated for a shorter time than unrelated words. The group

4 (RA vs. DS) and word type (homophones vs. unrelated words) interaction was

5 significant in RP and TT. The group (DS vs. CA) and word type (homophones vs.

6 unrelated words) interaction was not significant in RP but was significant in TT. In RP,

7 for the CA controls and the DS, there was no significant homophone advantage (CA: $b$

$8=-0.07, S E=0.04, t=-1.61$; DS: $b=0.00, S E=0.04, t=0.07)$, for the RA controls,

9 there was a significant homophone advantage $(b=-0.20, S E=0.05, t=-3.86)$. In TT,

10 for the CA and the RA, there was a significant homophone advantage (CA: $b=-0.24$,

$11 S E=0.04, t=-6.54$; RA: $b=-0.25, S E=0.04, t=-6.52)$, but for the DS, there was no

12 significant homophone advantage $(b=-0.02, S E=0.04, t=-0.52)$. In the group main

13 effects, the reading time of RA controls was significantly longer than the DS in RP and

14 TT. However, there was no significant difference between the DS and CA controls in

$15 \mathrm{RP}$ and TT.

In summary, and as shown in Table 4, a significant homophone advantage was

17 observed for both control groups in TT. Homophones were fixated for significantly

18 shorter durations than unrelated words, and we also found that the RA controls showed

19 a significant homophone advantage in regression out and RP. However, For the DS

20 group, there was no evidence for a significant homophone advantage in all eye

21 movement measures.

The results clearly show that reading ability can impact upon performance in the

23 current experiment, and that the RA group had more regressions out, longer GD, longer

$24 \mathrm{RP}$, and longer TT in comparison to the DS group. Additionally, the RA group showed 
Scientific Studies of Reading

\section{Running head: PHONOLOGICAL CODING IN CHINESE DEAF READERS}

1 a homophone advantage in the regression out, the RP, and the TT measures. However, it

2 should be noted that the deaf students in the current study had large individual

3 differences in reading ability, and these were not controlled for in the initial analyses of

4 the data. Therefore, reading ability within the DS group could be a factor that affects

5 whether phonological coding is activated during sentence reading in the deaf. For

6 example, previous studies have found that the use of phonological information is related

7 to the reading level of deaf readers (Perfetti \& Sandak, 2000; Wang, Trezek, Luckner,

$8 \&$ Paul, 2008). Furthermore, Yan et al. (2015) have found that more-skilled Chinese

9 deaf readers show a phonological preview benefit compared to less-skilled Chinese deaf

10 readers (the test of classification was reading fluency). In order to examine whether

11 Chinese deaf students' individual differences in reading level are related to the use of

12 phonological coding, we divided the deaf students in the current study into more-skilled

13 and less-skilled readers, according to reading fluency (the fluency test needed

14 participants to make a value judgment following each sentence, and hence this test also

15 includes comprehension).

\section{More-skilled deaf students compared with less-skilled deaf students}

17 In line with a previous study (Häikiö, Bertram, Hyönä, \& Niemi, 2009), we used a median split procedure to categorize the deaf student participants into two subgroups, based on their silent-reading fluency score. The median (score $=310.67$ ) is the standard

20 cut off point for characterising readers as being more-skilled or less-skilled. Using that

21 criteria we divided the sample of deaf students into less-skilled (LSKD) and more-

22 skilled (MSKD) students, and the reading fluency of these two subgroups was significantly different $(t=-7.36, p<0.001)$, the reading comprehension was significantly different $(t=-3.06, p<0.05)$, but the IQ and age of these two subgroups 
Scientific Studies of Reading

\section{Running head: PHONOLOGICAL CODING IN CHINESE DEAF READERS}

1 was not significantly different (IQ: $t=-0.24, p>0.05$; age: $t=0.84, p>0.05$ ). Means

2 for each dependent measure, broken down by participant group and experimental

3 condition, are shown in Table 5. We then ran a linear mixed-effects model with group

4 (MSKD vs. LSKD), and word type (homophone vs. unrelated) as fixed factors. The

5 results of this model for the eye movement measures are shown in Table 6.

6

7

$8 \quad$ Early-stage measures

9 There was no significant difference between homophones and unrelated words in FFD,

10 GD, and regression out. The difference was not significant for group in FFD, GD, and

11 regression out. The interaction between group and word type was not significant in FFD

12 and regression out, however, it was significant in GD. For the MSKD, there was no

13 significant homophone advantage $(b=-0.09, S E=0.05, t=-1.71)$, and for the LSKD,

14 there was no significant homophone advantage ( $b=0.08, S E=0.05, t=1.68)$.

\section{$15 \quad$ Late-stage measures}

16 There was no significant difference between homophones and unrelated words in RP

17 and in TT. The difference was not significant for group in RP, however, the group main

18 effect was significant in TT, the MSKD's TT were longer than the LSKD. The

19 interaction between group and word type was not significant in RP, but the interaction

20 was significant in TT. For the MSKD, there was a marginal significant homophone

21 advantage $(b=-0.10, S E=0.05, t=-1.94)$, whereas for the LSKD, there was no 
Scientific Studies of Reading

\section{Running head: PHONOLOGICAL CODING IN CHINESE DEAF READERS}

In summary the results provide evidence of a homophone advantage in the

2 MSKD for the TT measure. These data are presented in Figure 1. The evidence for this

3 advantage was then verified by comparing the MSKD with the two control groups in the

4 study. This comparison showed that the group (RA vs. MSKD) and word type

5 (homophone vs. unrelated) interaction was not significant in $\mathrm{RP}(b=0.13, S E=0.09, t$

$6=1.42)$, however it was significant in TT $(b=0.16, S E=0.07, t=2.11)$, and the group

7 (MSKD vs. CA) and word type (homophone vs. unrelated) interaction were not

8 significant in RP and TT (RP: $b=0.01, S E=0.09, t=0.12$; TT: $b=-0.13, S E=0.07, t$

$9=-1.80$ ). The findings from this comparison suggests that the MSKD group were

10 equivalent to the CA group and the RA group in showing a TT homophone advantage,

11 but this advantage was a smaller than the one shown by the RA group. This is likely to

12 reflect more regressions being made by the younger RA group, as reported earlier.

\section{More-skilled RA students compared with less-skilled $\boldsymbol{R A}$ students}

14 Since the deaf students were matched on reading ability to the RA group, we also

15 divided the RA group into more-skilled and less skilled readers, and we compared these

16 two sub-groups (the results are presented in Appendices 3). Both subgroups showed a

17 homophone advantage.

\section{Discussion}

20 This study investigated the role of phonological coding during sentence reading in

21 Chinese deaf middle school students. For the RA group, homophones produced

22 significantly shorter regression path time and total reading time than unrelated words,

23 and homophones produced less regression out than unrelated words. For the CA group, 


\section{Scientific Studies of Reading}

\section{Running head: PHONOLOGICAL CODING IN CHINESE DEAF READERS}

1 homophones produced significantly shorter total reading time than unrelated words.

2 These data indicated that both chronologically age matched, and reading ability

3 matched groups showed a homophone advantage. There was no evidence of a

4 homophone advantage in the deaf students. However, when the deaf students were

5 divided into more-skilled and less-skilled students, the homophone advantage was

6 observed for the more-skilled deaf students, and this advantage was absent in the less-

7 skilled deaf students. Overall, our analysis of the data for the two subgroups of deaf

8 students (more-skilled and less-skilled) provide evidence to suggest that more-skilled

9 deaf students use phonological coding during sentence reading, whereas less-skilled

10 deaf students do not.

11 This study found significant differences between homophones and unrelated

12 words in the later eye movement measures (total reading time) for hearing control

13 groups, and the total reading time on homophones was remarkably shorter than those

14 for unrelated words. This indicates that phonological coding occurs at the later lexical

15 identification stage in typical students reading Chinese sentences. However, we also

16 found the RA controls showed a homophone advantage in the regression out and the

17 regression path time measures, whereas the CA controls did not. We interpret this

18 finding to indicate that phonological information may play an important role in the

19 integration process of sentences for the CA controls. However, the RA controls who

20 were much younger hearing students showed a homophone advantage for both early and

21 later lexical identification measures. These time course differences in the control groups

22 may simply be related to age, since Chinese readers who are at the early stages of

23 learning to read, are taught using hanyu pinyin (Yan, Miller, Li, \& Shu, 2008) and have 
Scientific Studies of Reading

\section{Running head: PHONOLOGICAL CODING IN CHINESE DEAF READERS}

1 been proposed to rely on phonological mediation, unlike skilled readers who have been

2 shown to have more direct access to semantics from orthography (Zhou et al., 2017).

In the present study, the hearing students were composed of primary and middle

4 school students. The current findings show that both primary school and middle school

5 students can process phonology during lexical identification in silent sentence reading.

6 Therefore, for hearing students, the results from the current study extend previous

7 findings on phonological activation of word meanings during reading, and they support

8 the evidence for a benefit in later eye movement measures for college students (Feng et

$9 \quad$ al., 2001; Wong \& Chen, 1999).

10 In general, the present study showed no significant differences between

11 homophones and unrelated words in all eye movement measures for the deaf students

12 when they were analysed as a single group. This finding would seem to support the

13 viewpoint that deaf students cannot activate phonological coding during silent sentence

14 reading (Bélanger et al., 2012; Fariña, et al., 2017). However, there are large individual

15 reading ability differences in the deaf, and Mayberry et al. (2011) have emphasised that

16 in studies of deaf readers, few studies control for individual differences in reading levels

17 within the deaf group. When the deaf students in the current study were divided into

18 more-skilled and less-skilled students, a similar homophone advantage was observed for

19 the total reading time measures, and this advantage was exclusive to the more skilled

20 readers amongst the deaf students. Therefore, the statement above that suggested that

21 deaf readers do not activate phonological coding has been qualified to now refer to less

22 skilled deaf readers. Consistent with previous research (Daigle \& Armand, 2007;

23 Furlonger, Holmes, \& Rickards, 2014; Hanson \& Fowler, 1987), our results showed

24 that the use of phonology is associated with higher levels of reading skill in Chinese 
Scientific Studies of Reading

\section{Running head: PHONOLOGICAL CODING IN CHINESE DEAF READERS}

1 deaf readers. This is not the case for the RA controls in this study, since both more

2 skilled and less skilled readers in that group showed a homophone advantage (see

3 Appendices 3). Therefore, it is not reading ability per se that prevents the use of

4 phonological coding in the less skilled deaf readers in this study.

Since the more skilled deaf readers showed the same effects for the homophones

6 as the control groups, we can infer that they have made use of phonological coding

7 during reading sentences in this experiment. However, the less skilled deaf readers did

8 not show the homophone advantage, indicating that they were unable to use

9 phonological coding when they read the sentences. An obvious question relates to why

10 less skilled deaf readers are unable to activate phonological coding during sentence

11 reading. Morford, Kroll, Piñar, and Wilkinson (2014), Meade, Midgley, Sehyr,

12 Holcomb, and Emmorey (2017) found that deaf readers who were less skilled in their

13 English were more likely to use sign translations. It could therefore be the case that the

14 less skilled deaf readers rely on sign phonology during reading, and the more skilled

15 deaf readers rely on sound phonology. The reason that there are shorter reading times

16 and regressions for homophones, compared to unrelated words, is that the homophones

17 share the same sound phonology as the correctly spelled words. The literature suggests

18 that deaf readers do engage in sign phonology during reading (Bélanger, Morford, \&

19 Rayner, 2013; Morford, Wilkinson, Villwock, Piñar, \& Kroll, 2011; Ormel, Hermans,

20 Knoors, \& Verhoeven, 2012; Pan, Shu, Wang, \& Yan, 2015; Treiman \& Hirsh-Pasek,

21 1983). However, it is not known whether deaf readers who engage in sign phonology

22 during reading are less skilled deaf readers. What is known is that if readers are using

23 sign phonology, then one would not expect to see the homophone advantage during

24 reading, as there is no equivalent sign phonology for written homophones. Specifically, 
Scientific Studies of Reading

\section{Running head: PHONOLOGICAL CODING IN CHINESE DEAF READERS}

1 sign phonology includes four formational parameters: handshape, location, movement,

2 and orientation (Battison, 1978; Stokoe, Croneberg, \& Casterline, 1965), and sign-

3 phonological relatedness has been defined as sharing at least two formational

4 parameters (Ormel et al., 2012). In the present study, the sign phonology of target

5 characters in the sentences do not share any two sign formational parameters. This

6 means that, in the current study, there is no equivalent sign phonology for the written

7 homophones.

A further question that arises from the findings in the present study relates to

9 what underpins whether a deaf person becomes a more skilled or a less skilled reader.

10 According to Musselman (2000), if the reading processing of the more-skilled deaf

11 reader is similar to that of hearing readers, we can speculate that the reason for

12 difficulty in reading in that group is due to a delay in their reading development, caused

13 by hearing loss. However, if the reading processing of the less-skilled deaf reader is

14 different to that of hearing readers, and, if that group relies more on sign language

15 representation in the reading process (see Bélanger et al., 2012; Sterne \& Goswami,

16 2000), then we can infer that the reason for difficulty in reading in the less skilled

17 readers may reflect atypical (rather than delayed) reading development.

In summary, the results of the present study have important theoretical

implications as they suggest that not all deaf readers develop reading skills in the same

20 way. If it is the case that less-skilled deaf students rely more on sign phonology, this

21 could prevent them from being able to use phonological coding during reading. The

22 results also have important practical implications for the teaching methods of deaf

23 readers. Methods designed to improve reading may have to be tailored for deaf students

24 who may rely more on sign phonology, since these students may need to be taught to 
Scientific Studies of Reading

\section{Running head: PHONOLOGICAL CODING IN CHINESE DEAF READERS}

1 develop and build the connections between the written language forms and sign

2 language.

\section{Conclusion}

4 This investigation of phonological coding in deaf Chinese readers has shown that more-

5 skilled Chinese deaf readers use phonological coding during sentence reading, whereas

6 less-skilled Chinese deaf readers do not. We hypothesise that reading difficulties in

7 Chinese more-skilled deaf students may be due to delayed reading development,

8 whereas reading difficulties in Chinese less-skilled deaf students may reflect atypical

9 reading development, but we concur that these hypotheses remain to be empirically

10 tested. What is of further interest for future research is to investigate why some deaf

11 readers are able to activate phonological coding during reading, whereas other are not.

\section{Acknowledgement}

13 This research was supported by the National Social Science Fund of China

14 (16BYY074) and Rrsearch Grant from Tianjin Normal University.

\section{Ethics approval}

16 This study was conducted in accordance with the principles of the Declaration of

17 Helsinki and was approved by the Research Ethics Committee at Tianjin Normal

18 University. Participants' legal guardians gave informed consent and each participant

19 provided written informed consent before taking part in the study.

\section{Conflict of interest}

21 The authors declare no conflict of interest. 
Scientific Studies of Reading

\section{Running head: PHONOLOGICAL CODING IN CHINESE DEAF READERS}

\section{References}

2 Bai, X., Yan, G., Liversedge, S. P., Zang, C., \& Rayner, K. (2008). Reading spaced and unspaced Chinese text: Evidence from eye movements. Journal of Experimental Psychology: Human Perception \& Performan, 34(5), 1277-1287.

Bates, D., Maechler, M., \& Dai, B. (2009). lme4: Linear mixed-effects models using S4 classes. 2009. R Package, version, 999375-31.

7 Battison, R. (1978). Lexical borrowing in American Sign Language. Silver Spring, MD: Linstok Press.

9 Bélanger, N. N., Baum, S. R., \& Mayberry, R. I. (2012). Reading difficulties in adult deaf readers of French: Phonological codes, not guilty! Scientific Studies of Reading, $16(3), 263-285$.

Bélanger, N. N., Mayberry, R. I., \& Rayner, K. (2013). Orthographic and phonological preview benefits: Parafoveal processing in skilled and less-skilled deaf readers. Quarterly Journal of Experimental Psychology, 66(11), 2237-2252.

Bélanger, N. N., Morford, J. P., \& Rayner, K. (2013, August). Automatic American Sign Language (ASL) activation during reading in ASL-English deaf bilinguals. Paper presented at the 17th European Conference on Eye Movements, Lund, Sweden.

Blythe, H. I., Dickins, J. H., Kennedy, C. R., \& Liversedge, S. P. (2018). Phonological processing during silent reading in teenagers who are deaf/hard of hearing: An eye movement investigation. Developmental Science, 21(5), e12643.

Blythe, H. I., Pagán, A., \& Dodd, M. (2015). Beyond decoding: Phonological 
Scientific Studies of Reading

\section{Running head: PHONOLOGICAL CODING IN CHINESE DEAF READERS}

1 Coltheart, M., Rastle, K., Perry, C., Ziegler, J., \& Langdon, R. (2001). DRC: A dual

2 route cascades model of visual word recognition and reading aloud. Psychological 3 Review, 108(1), 204-256.

4 Daigle, D., \& Armand, F. (2007). Phonological sensitivity in severely and profoundly deaf readers of French. Reading and Writing, 21(7), 699-717.

6 Daneman, M., \& Reingold, E. (1993). What eye fixations tell us about phonological recoding during reading. Canadian Journal of Experimental Psychology, 47(2),

Furlonger, B., Holmes, V. M., \& Rickards, F. W. (2014). Phonological awareness and 153-178.

Fariña, N., Duñabeitia, J. A., \& Carreiras, M. (2017). Phonological and orthographic coding in deaf skilled readers. Cognition, 168, 27-33.

Feng, G., Miller, K., Shu, H., \& Zhang, H. (2001). Rowed to recovery: The use of phonological and orthographic information in reading Chinese and English. Journal of Experimental Psychology: Learning Memory \& Cognition, 27(4), 1079-1110.

Friesen, D. C., \& Joanisse, M. F. (2012). Homophone effects in deaf readers: Evidence from lexical decision. Reading and Writing, 25(2), 375-388.

Friesen, D. C., Whitford, V., Titone, D., \& Jared, D. (2020). The impact of individual differences on cross-language activation of meaning by phonology. Bilingualism: Language and Cognition, 23(2), 323-343.

Grainger, J., \& Ferrand, L. (1994). Phonology and orthography in visual word recognition: Effects of masked homophone primes. Journal of Memory and Language, 33(2), 218-233. 
Scientific Studies of Reading

\section{Running head: PHONOLOGICAL CODING IN CHINESE DEAF READERS}

1 Häikiö, T., Bertram, R., Hyönä, J., \& Niemi, P. (2009). Development of the letter

2 identity span in reading: Evidence from the eye movement moving window

3 paradigm. Journal of Experimental Child Psychology, 102(2), 167-181.

4 Hanson, V. L., \& Fowler, C. A. (1987). Phonological coding in word reading: Evidence

5 from hearing and deaf readers. Memory \& Cognition, 15(3), 199-207.

6 Hanson V. L., Goodell E. W., \& Perfetti C. A. (1991). Tongue-Twister effects in the

$7 \quad$ silent reading of hearing and deaf college students. Journal of Memory and

$8 \quad$ Language, 30(3), 319-330.

9 Harris, M., \& Moreno, C. (2004). Deaf children's use of phonological coding: Evidence

10 from reading, spelling, and working memory. Journal of Deaf Studies and Deaf

11 Education, 9(3), 253-68.

12 Hirshorn, E. A., Dye, M. W., Hauser, P., Supalla, T. R., \& Bavelier, D. (2015). The contribution of phonological knowledge, memory, and language background to

Ho, C. S.-H., \& Bryant, P. (1997). Phonological skills are important in learning to read 16 Chinese. Developmental Psychology, 33(6), 946-951.

Jared, D., Ashby, J., Agauas, S. J., \& Levy, B. A. (2016). Phonological activation of word meanings in grade 5 readers. Journal of Experimental Psychology: Learning Memory \& Cognition, 42(4), 524-541.

Jared, D., \& O’Donnell, K. (2017). Skilled adult readers activate the meanings of highfrequency words using phonology: Evidence from eye tracking. Memory \& Cognition, 43(2), 334-346.

Kyle, F. E., \& Cain, K. (2015). A comparison of deaf and hearing children's reading comprehension profiles. Topics in Language Disorders, 35(2), 144-156. 
Scientific Studies of Reading

\section{Running head: PHONOLOGICAL CODING IN CHINESE DEAF READERS}

1 Lee, H. W., Rayner, K., \& Pollatsek, A. (1999). The time course of phonological,

2 semantic and orthographic coding in reading: Evidence from the fast-priming

3 technique. Psychonomic Bulletin \& Review, 6(4), 624-634.

4 Lei, L., Pan, J., Liu, H., McBride-Chang, C., Li, H., Zhang, Y., ... Shu, H. (2011).

5 Developmental trajectories of reading development and impairment from ages 3 to

68 years in Chinese children. Journal of Child Psychology and Psychiatry, 52(2),

$7 \quad 212-220$.

8 Li, L. P., Wu, X. C., Zhou, N. N., Chen, Y. H., \& Nguyen, T. P. (2016). The cognitive

$9 \quad$ characteristics and influential factors of Chinese word callers in primary school.

10 Acta Psychologica Sinica, 48(10), 1270-1281.

11 Lukatela, G., Frost, S. J., \& Turvey M. T. (1998). Phonological priming by masked

12 nonword primes in the lexical decision task. Journal of Memory and Language,

$13 \quad 39(4), 666-683$.

14 Mayberry, R. I., del Giudice, A. A., \& Lieberman, A. M. (2011). Reading achievement

15 in relation to phonological coding and awareness in deaf readers: A meta-analysis.

16 Journal of Deaf Studies and Deaf Education, 16(2), 164-188.

17 McQuarrie, L., \& Parrila, R. (2008). Phonological representations in deaf children:

18 Rethinking the "functional equivalence" hypothesis. Journal of Deaf Studies and

19 Deaf Education, 14(2), 137-154.

20 Meade, G., Midgley, K. J., Sehyr, Z. S., Holcomb, P. J., \& Emmorey, K. (2017).

21 Implicit co-activation of American sign language in deaf readers: An ERP study.

22 Brain \& Language, 170, 50-61.

23 Morford, J. P., Kroll, J. F., Piñar, P., \& Wilkinson, E. (2014). Bilingual word

24 recognition in deaf and hearing singers: Effects of proficiency and language 
Scientific Studies of Reading

\section{Running head: PHONOLOGICAL CODING IN CHINESE DEAF READERS} dominance on cross-language activation. Second Language Research, 30(2), 251271.

Morford, J. P., Wilkinson, E., Villwock, A., Piñar, P., \& Kroll, J. F. (2011). When deaf signers read English: Do written words activate their sign translations? Cognition, $118(2), 286-292$.

Musselman, C. (2000). How do children who can't hear learn to read an alphabetic script? A review of the literature on reading and deafness. Journal of Deaf Studies and Deaf Education, 5(1), 9-31.

Ormel, E., Hermans, D., Knoors, H., \& Verhoeven, L. (2012). Cross-language effects in written word recognition: The case of bilingual deaf children. Bilingualism: Language and Cognition, 15(2), 288-303.

Pan, J., McBride-Chang, C., Shu, H., Liu, H., Zhang, Y., \& Li, H. (2011). What is in the naming? A 5-year longitudinal study of early rapid naming and phonological sensitivity in relation to subsequent reading skills in both native Chinese and English as a second language. Journal of Educational Psychology, 103(4), 897908.

Pan, J., Shu, H., Wang, Y. L., \& Yan, M. (2015). Parafoveal activation of sign translation previews among deaf readers during the reading of Chinese sentences. Memory \& Cognition, 43(6),964-972.

Paul, P. V., \& Lee, C. (2010). The qualitative similarity hypothesis. American Annals of the Deaf, 154(5), 456-462.

Perea, M., Marcet, A., \& Vergara-Martínez, M. (2016). Phonological-lexical feedback during early abstract encoding: The case of deaf readers. Plos One, 11(1), e0146265. 
Scientific Studies of Reading

\section{Running head: PHONOLOGICAL CODING IN CHINESE DEAF READERS}

1 Perfetti, C. A., \& Sandak, R. (2000). Reading optimally builds on spoken language: 2 Implications for deaf readers. Journal of Deaf Studies and Deaf Education, 5(1), 32350.

4 Raven, J. C., Court, J. H., \& Raven, J. (1996). Standard Progressive Matrices. Oxford: Oxford Psychologists Press.

6 Rayner, K., Pollatsek, A., \& Binder, K. S. (1998). Phonological codes and eye movements in reading. Journal of Experimental Psychology: Learning Memory \& Cognition, 24(2), 476-497.

R Development Core Team. (2012). R: A language and environment for statistical computing, R Foundation for Statistical Computing. Vienna, Austria.

Schotter, E. R., Angele, B., \& Rayner, K. (2012). Parafoveal processing in reading.

$$
\text { Attention Perception \& Psychophysics, 74(1), 5-35. }
$$

13 Sterne, A., \& Goswami, U. (2000). Phonological awareness of syllables, rhymes and 14 phonemes in deaf children. Journal of Child Psychology and Psychiatry, 41(5), 609-626.

Stokoe, W., Croneberg, C., \& Casterline, D. (1965). A dictionary of American Sign Language on linguistic principles. Washington, DC: Gallaudet College Press.

Tan, L.H., \& Perfetti, C.A. (1998). Phonological codes as early sources of constraint in Chinese word identification: A review of current discoveries and theoretical accounts. Reading and Writing, 10(3-5), 165-200.

21 Transler, C., \& Reitsma, P. (2005). Phonological coding in reading of deaf children: Pseudohomophone effects in lexical decision. British Journal of Developmental Psychology, 23(4), 525-542.

24 Treiman, R., \& Hirsh-Pasek, K. (1983). Silent reading: Insights from second-generation 
Scientific Studies of Reading

\section{Running head: PHONOLOGICAL CODING IN CHINESE DEAF READERS} deaf readers. Cognitive Psychology, 15(1), 39-65.

Wang, Y., Trezek, B., Luckner, J., \& Paul, P. V. (2008). The role of phonology and phonologically related skills in reading instruction for students who are deaf or hard of hearing. American Annals of the Deaf, 153(4), 396-407.

Wauters, L. N., van Bon, W. H. J., \& Tellings, A. E. J. M. (2006). Reading comprehension of Dutch deaf children. Reading and Writing, 19(1), 49-76.

Wong, K. F. E. \& Chen, H. C. (1999). Orthographic and phonological processing in reading Chinese text: Evidence from eye fixations. Language and Cognitive Processes, 14(5-6), 461-480.

Yan, M., Miller, K.F., Li, H. \& Shu, H. (2008). What is the place for pinyin in beginning Chinese reading? Evidence from eye-movement research. In K. Rayner, D. Shen, X. Bai \& G. Yan (Eds.), Cognitive and cultural influences on eye movements, (pp. 343-360). New York: Psychology Press.

Yan, M., Pan, J. G., Bélanger, N. N., \& Shu, H. (2015). Chinese deaf readers have early access to parafoveal semantics. Journal of Experimental Psychology: Learning, Memory, and Cognition, 41(1), 254-261.

Zhou, W., Shu, H., Miller, K., \& Yan, M. (2017). Reliance on orthography and phonology in reading of Chinese: A developmental study. Journal of Research in Reading. 41(2), 370-391.

Zhou, X. L., \& Marslen-Wilson, W. (2000). The relative time course of semantic and phonological activation in reading Chinese. Journal of Experimental Psychology: Learning Memory and Cognition, 26(5), 1245-1265. 
Page 31 of 44

Scientific Studies of Reading

Running head: PHONOLOGICAL CODING IN CHINESE DEAF READERS

1 Ziegler, J. C., \& Goswami, U. (2005). Reading acquisition, developmental dyslexia, and

2 skilled reading across languages: A psycholinguistic grain size theory.

3 Psychological Bulletin, 131(1), 3-29.

4

5 
Page 32 of 44

Scientific Studies of Reading

\section{Running head: PHONOLOGICAL CODING IN CHINESE DEAF READERS}

\section{Appendices 1}

2 In this section, we document our experiment materials. Target words are formatted in

3 bold.

\begin{tabular}{|c|c|c|c|c|}
\hline item & sentence & $\begin{array}{c}\text { Correctly } \\
\text { spelled }\end{array}$ & Homophone & Unrelated \\
\hline 1 & 明亮温暖的阳光轻轻地酒落在草原上。 & 阳 & 洋 & 绝 \\
\hline 2 & 为家人做饭是一件轻松愉快的事情。 & 轻 & 清 & 格 \\
\hline 3 & 王小明一想到减法就会感到头疼。 & 减 & 检 & 顾 \\
\hline 4 & 自然界有很多奇怪的现象在等我们发现。 & 奇 & 齐 & 冬 \\
\hline 5 & 清晨的荷叶上挂着很多晶亮的小水珠。 & 晶 & 惊 & 预 \\
\hline 6 & 园丁说把这种兰花种在花园里会更好。 & 兰 & 蓝 & 票 \\
\hline 7 & 小军很喜欢夏天荷花盛开的景象。 & 夏 & 吓 & 巩 \\
\hline 8 & 童年时在乡下的日子是我难忘的回忆。 & 乡 & 香 & 免 \\
\hline 9 & 长大后成为医生是我儿时的梦想。 & 医 & 衣 & 含 \\
\hline 10 & 清洁工人把校园打扫得非常干净。 & 校 & 笑 & 爱 \\
\hline 11 & 那支长长的队伍行走在冰天雪地里。 & 冰 & 兵 & 号 \\
\hline 12 & 妹妹被一阵响声吓得不敢出门了。 & 响 & 享 & 弃 \\
\hline 13 & 我已经忘记这座城市是什么样子了。 & 城 & 承 & 穿 \\
\hline 14 & 刘老师领着我走到了班级的讲台中央。 & 班 & 般 & 持 \\
\hline 15 & 听说王叔叔住在这个小区的东北角。 & 住 & 助 & 材 \\
\hline 16 & 这个小学校有很多姓名相同的人。 & 姓 & 兴 & 乐 \\
\hline 17 & 我们从河里一共捕到了十条小鱼。 & 捕 & 补 & 陆 \\
\hline 18 & 这个小店的蛋糕很受学生们的欢迎。 & 蛋 & 淡 & 绪 \\
\hline 19 & 每一个人都应该保护可爱的野生动物。 & 保 & 宝 & 序 \\
\hline 20 & 一束温暖的阳光照进了我的房间。 & 照 & 赵 & 购 \\
\hline 21 & 这片树林里的叶子在风中沙沙作响。 & 叶 & 夜 & 府 \\
\hline 22 & 我相信这片李子树明年就能开花结果。 & 李 & 礼 & 伙 \\
\hline 23 & 这家商店的员工服务又周到又热情。 & 服 & 福 & 端 \\
\hline 24 & 山谷里的河水叮叮咚咚地响了起来。 & 河 & 核 & 培 \\
\hline 25 & 一只小猫正在石头上安静地睡觉。 & 石 & 识 & 规 \\
\hline 26 & 这件新衣服的布料又漂亮又舒服。 & 布 & 步 & 至 \\
\hline 27 & 校园里的梅花在冬天开出了美丽的花朵。 & 冬 & 东 & 区 \\
\hline 28 & 这个著名歌手的声音非常的好听。 & 歌 & 割 & 峰 \\
\hline 29 & 小杰新买的背包看起来漂亮极了。 & 背 & 悲 & 赏 \\
\hline 30 & 田野里的谷物到了秋天都会变成黄色的。 & 谷 & 古 & 台 \\
\hline 31 & 王老师家里有急事所以不能来上课了。 & 急 & 级 & 话 \\
\hline 32 & 白雪公主一直记得那个帮助过她的人。 & 记 & 计 & 设 \\
\hline 33 & 花花一个人坐在树下给弟弟洗衣服。 & 树 & 数 & 题 \\
\hline 34 & 军人每年和亲人见面的次数很少。 & 亲 & 侵 & 损 \\
\hline 35 & 公园里每年春天的景色都非常美丽。 & 景 & 井 & 贝 \\
\hline 36 & 夜晚的学校阴森森的让他们感到害怕。 & 阴 & 音 & 觉 \\
\hline 37 & 弟弟在河边光着脚 Y等妈妈一起回家。 & 脚 & 角 & 考 \\
\hline 38 & 小花狗正向拿着骨头的我摇尾巴。 & 骨 & 股 & 洞 \\
\hline 39 & 学校把学生活动的场所放在了体育场。 & 场 & 厂 & 毛 \\
\hline
\end{tabular}


Scientific Studies of Reading

Running head: PHONOLOGICAL CODING IN CHINESE DEAF READERS

\begin{tabular}{|l|l|l|l|l|}
40 & 他觉得这门课程的考试非常困难。 & 课 & 客 \\
\hline 41 & 家中唯一的洗衣机被阿朵弄坏了。 & 洗 & 喜 & 简 \\
\hline 42 & 在温暖的窝里沉睡的小猫非常可爱。 & 沉 & 陈 & 词 \\
\hline 43 & 要想成为一名画家是需要自己多努力的。 & 画 & 划 & 约 \\
\hline 44 & 小姑娘决定剪掉那一头乌黑发亮的头发。 & 乌 & 屋 & 贵 \\
\hline 45 & 医学专家说鸡肉对病人的身体有好处。 & 鸡 & 击 & 巴 \\
\hline
\end{tabular}

1

2

3

4

5

6

7

8

9

10

11

12

13

14

15

16

17

18

19

20

21 
Scientific Studies of Reading

\section{Running head: PHONOLOGICAL CODING IN CHINESE DEAF READERS}

\section{$1 \quad$ Appendices 2}

2 In this section, we document results for the correctly spelled condition.

\section{Early-stage measures}

\section{Correctly spelled words vs. homophones}

5 Correctly spelled words were fixated shorter than homophones in FFD $(b=0.07, S E=$

$60.02, t=4.77)$, and GD $(b=0.21, S E=0.02, t=9.42)$. The interactions between group

7 (RA vs. DS) and word type were not significant in FFD ( $b=-0.06, S E=0.04, t=-1.69)$,

8 however, in GD were significant $(b=-0.17, S E=0.05, t=-3.08)$. The interactions

9 between group (DS vs. CA) and word type were significant in FFD ( $b=0.08, S E=$ $100.04, t=2.02)$, and GD $(b=0.13, S E=0.06, t=2.35)$. In regression out, there was no

11 significant difference between correctly spelled words and homophones $(b=0.20, S E=$

$120.11, z=0.07)$. The interactions between group and word type were not significant $(|z|<$ 13 0.75).

\section{Correctly spelled words vs. unrelated words}

15 Correctly spelled words were fixated shorter than unrelated words in FFD $(b=-0.06, S E$ $16=0.02, t=-3.80)$, and GD $(b=-0.22, S E=0.02, t=-9.91)$. The interactions between 17 group (RA vs. DS) and word type were not significant in FFD $(b=0.03, S E=0.04, t=$ $180.84)$, however, in GD were significant $(b=0.21, S E=0.05, t=3.89)$. The interactions 19 between group (DS vs. CA) and word type were not significant in FFD $(b=0.04, S E=$ $200.04, t=1.07)$, however, in GD were significant $(b=0.12, S E=0.06, t=2.12)$. In 21 regression out, correctly spelled words produced less regression out than unrelated 22 words $(b=0.52, S E=0.11, z=4.74)$. The interactions between group (RA vs. DS) and word type were significant $(b=0.63, S E=0.28, z=2.27$ ), however, the interactions 
Scientific Studies of Reading

\section{Running head: PHONOLOGICAL CODING IN CHINESE DEAF READERS}

1 between group (DS vs. CA) and word type were not significant $(b=-0.54, S E=0.29, z$ $2=-1.86)$.

\section{Late-stage measures}

4 Correctly spelled words vs. homophones

5 Correctly spelled words were fixated shorter than homophones in RP $(b=0.27, S E=$

$60.03, t=9.89)$, and TT $(b=0.42, S E=0.03, t=15.20)$. The interactions between group

7 and word type were significant in $\mathrm{RP}(|t s|>3.16)$, and TT $(|t s|>2.06)$.

$8 \quad$ Correctly spelled words vs. unrelated words

9 Correctly spelled words were fixated shorter than unrelated words in RP $(b=-0.35, S E$

$10=0.03, t=-12.79)$, and TT $(b=-0.59, S E=0.02, t=-26.55)$. The interactions between

11 group and word type were significant in RP $(|t s|>4.21)$, and TT $(|t s|>6.40)$. 
Scientific Studies of Reading

\section{Running head: PHONOLOGICAL CODING IN CHINESE DEAF READERS}

\section{Appendices 3}

2 In this section, we document results for the more-skilled and less-skilled RA group. We

3 divided the RA group into more-skilled and less-skilled readers in terms of their reading

4 fluency. We then ran a linear mixed-effects model with group (MSKD vs. LSKD), and

5 word type (homophone vs. unrelated) as fixed factors. The results showed that the

6 interactions between group and word type were not significant in FFD $(b=0.09, S E=$

$70.06, t=1.45), \mathrm{GD}(b=0.08, S E=0.09, t=0.82)$, regression out $(b=0.47, S E=0.33, z$

$8=1.43), \operatorname{RP}(b=0.17, S E=0.11, t=1.61)$, and TT $(b=0.06, S E=0.08, t=0.79)$. 
Page 37 of 44

Scientific Studies of Reading

Running head: PHONOLOGICAL CODING IN CHINESE DEAF READERS

\section{Table 1}

Nonverbal IQ, reading fluency, reading comprehension, and age for RA and DS groups.

\begin{tabular}{cccccc}
\hline & RA & DS & MSKD & LSKD & $t$ \\
& $M(S D)$ & $M(S D)$ & $M(S D)$ & $M(S D)$ & \\
\hline $\begin{array}{c}\text { Nonverbal IQ } \\
\text { (standardised) }\end{array}$ & $59.50(23.23)$ & $50.84(21.01)$ & $53.14(22.48)$ & $46.69(19.27)$ & 1.67 \\
$\begin{array}{l}\text { Reading fluency } \\
\text { (characters/min) }\end{array}$ & $297.00(182.10)$ & $295.72(143.77)$ & $428.40(103.49)$ & $200.29(60.84)$ & 0.04 \\
$\begin{array}{c}\text { Reading comprehension } \\
\text { (score) }\end{array}$ & $8.84(2.16)$ & $8.37(3.42)$ & $10.43(2.82)$ & $7(3.31)$ & 0.65 \\
Age (years) & $10.74(0.34)$ & $17.37(1.74)$ & $17.31(1.96)$ & $17.82(1.38)$ & -20.87 \\
\hline
\end{tabular}

Note: DS group included More-skilled DS (MSKD) and Less-skilled DS (LSKD). The t tests were contrasted between RA and DS groups. 
Scientific Studies of Reading

\section{Running head: PHONOLOGICAL CODING IN CHINESE DEAF READERS}

\section{Table 2}

Character properties of the three experimental conditions

\begin{tabular}{lccc}
\hline & Correctly spelled & Homophone & Unrelated \\
& $M(S D)$ & $M(S D)$ & $M(S D)$ \\
\hline Character & 阳 & 洋 & 绝 \\
Pronunciation & Yang2 & Yang2 & Jue2 \\
Frequency & $269.04(21.89)$ & $245.42(25.30)$ & $245.46(25.21)$ \\
No. of strokes & $8.24(0.31)$ & $8.75(0.42)$ & $8.64(0.39)$ \\
\hline
\end{tabular}

Note. Means (and standard deviation $[S D]$ ) of frequency per million (Beijing Language Institute, 1986) and number of strokes are provided in the table. The target word (阳光, sunshine) is embedded into a sentence (明亮温暖的阳光轻轻地酒落在草原上), which is translated as: The bright and warm sunshine falls gently on the grassland. 
Scientific Studies of Reading

Running head: PHONOLOGICAL CODING IN CHINESE DEAF READERS

Table 3

Means and Standard Deviations for eye movement measures for the RA, DS, and CA groups.

\begin{tabular}{|c|c|c|c|c|c|c|c|c|c|}
\hline & \multicolumn{3}{|c|}{ RA } & \multicolumn{3}{|c|}{ DS } & \multicolumn{3}{|c|}{ CA } \\
\hline & $\mathrm{CO}$ & $\mathrm{HO}$ & UN & $\mathrm{CO}$ & $\mathrm{HO}$ & UN & $\mathrm{CO}$ & $\mathrm{HO}$ & UN \\
\hline FFD (ms) & $\begin{array}{c}273 \\
(124)\end{array}$ & $\begin{array}{c}302 \\
(142)\end{array}$ & $\begin{array}{c}298 \\
(151)\end{array}$ & $\begin{array}{c}268 \\
(113)\end{array}$ & $\begin{array}{c}275 \\
(118)\end{array}$ & $\begin{array}{c}276 \\
(111)\end{array}$ & $\begin{array}{l}237 \\
(90)\end{array}$ & $\begin{array}{c}268 \\
(110)\end{array}$ & $\begin{array}{c}261 \\
(114)\end{array}$ \\
\hline GD (ms) & $\begin{array}{c}371 \\
(243)\end{array}$ & $\begin{array}{c}520 \\
(367)\end{array}$ & $\begin{array}{c}566 \\
(423)\end{array}$ & $\begin{array}{c}339 \\
(204)\end{array}$ & $\begin{array}{c}380 \\
(230)\end{array}$ & $\begin{array}{c}380 \\
(222)\end{array}$ & $\begin{array}{c}278 \\
(143)\end{array}$ & $\begin{array}{c}379 \\
(228)\end{array}$ & $\begin{array}{c}387 \\
(273)\end{array}$ \\
\hline $\begin{array}{l}\text { Regression } \\
\text { out }\end{array}$ & $\begin{array}{c}0.25 \\
(0.43)\end{array}$ & $\begin{array}{c}0.29 \\
(0.44)\end{array}$ & $\begin{array}{c}0.40 \\
(0.49)\end{array}$ & $\begin{array}{c}0.14 \\
(0.35)\end{array}$ & $\begin{array}{c}0.15 \\
(0.36)\end{array}$ & $\begin{array}{c}0.16 \\
(0.36)\end{array}$ & $\begin{array}{c}0.17 \\
(0.38)\end{array}$ & $\begin{array}{c}0.22 \\
(0.41)\end{array}$ & $\begin{array}{c}0.28 \\
(0.45)\end{array}$ \\
\hline $\mathrm{RP}(\mathrm{ms})$ & $\begin{array}{c}584 \\
(494)\end{array}$ & $\begin{array}{c}879 \\
(753)\end{array}$ & $\begin{array}{l}1045 \\
(777)\end{array}$ & $\begin{array}{c}431 \\
(310)\end{array}$ & $\begin{array}{c}495 \\
(372)\end{array}$ & $\begin{array}{c}488 \\
(361)\end{array}$ & $\begin{array}{c}371 \\
(278)\end{array}$ & $\begin{array}{c}542 \\
(390)\end{array}$ & $\begin{array}{c}620 \\
(496)\end{array}$ \\
\hline TT (ms) & $\begin{array}{c}640 \\
(440)\end{array}$ & $\begin{array}{l}1084 \\
(668)\end{array}$ & $\begin{array}{l}1428 \\
(907)\end{array}$ & $\begin{array}{c}540 \\
(342)\end{array}$ & $\begin{array}{c}732 \\
(528)\end{array}$ & $\begin{array}{c}725 \\
(470)\end{array}$ & $\begin{array}{c}426 \\
(265)\end{array}$ & $\begin{array}{c}659 \\
(413)\end{array}$ & $\begin{array}{c}841 \\
(508)\end{array}$ \\
\hline Skip & $\begin{array}{c}0.18 \\
(0.38)\end{array}$ & $\begin{array}{c}0.15 \\
(0.35)\end{array}$ & $\begin{array}{c}0.12 \\
(0.33)\end{array}$ & $\begin{array}{c}0.20 \\
(0.40)\end{array}$ & $\begin{array}{c}0.16 \\
(0.37)\end{array}$ & $\begin{array}{c}0.20 \\
(0.40)\end{array}$ & $\begin{array}{c}0.24 \\
(0.43)\end{array}$ & $\begin{array}{c}0.21 \\
(0.41)\end{array}$ & $\begin{array}{c}0.19 \\
(0.39)\end{array}$ \\
\hline
\end{tabular}

Note: $\mathrm{CO}=$ correctly spelled words, $\mathrm{HO}=$ homophone words, $\mathrm{UN}=$ unrelated words.

1

2

3

4

5

6

7

8 
Scientific Studies of Reading

\section{Running head: PHONOLOGICAL CODING IN CHINESE DEAF READERS}

\section{Table 4}

Results from LMMs for eye movement measures for the RA, DS, and CA groups.

\begin{tabular}{|c|c|c|c|c|c|c|c|c|c|c|c|c|c|c|c|}
\hline & \multicolumn{3}{|c|}{ First fixation duration } & \multicolumn{3}{|c|}{ Gaze duration } & \multicolumn{3}{|c|}{ Regression out } & \multicolumn{3}{|c|}{$\begin{array}{l}\text { Regression path } \\
\text { time }\end{array}$} & \multicolumn{3}{|c|}{ Total reading time } \\
\hline & $b$ & $S E$ & $t$ & $b$ & $S E$ & $t$ & $b$ & $S E$ & $z$ & $b$ & $S E$ & $t$ & $b$ & $S E$ & $t$ \\
\hline Intercept & 5.51 & 0.02 & 287.00 & 5.77 & 0.03 & 187.52 & -1.41 & 0.10 & -13.65 & 6.08 & 0.04 & 164.50 & 6.41 & 0.04 & 182.51 \\
\hline DS-RA & -0.05 & 0.05 & -1.16 & -0.21 & $\mathbf{0 . 0 7}$ & -2.90 & -1.04 & 0.22 & -4.71 & -0.47 & 0.08 & -5.64 & -0.41 & 0.08 & -5.17 \\
\hline CA-DS & -0.07 & 0.05 & -1.58 & -0.08 & 0.07 & -1.08 & 0.52 & 0.22 & 2.35 & 0.02 & 0.08 & 0.26 & -0.06 & 0.08 & -0.79 \\
\hline $\mathrm{HO}-\mathrm{CO}$ & 0.07 & 0.02 & 4.77 & 0.21 & 0.02 & 9.42 & 0.20 & 0.11 & 0.07 & 0.27 & $\mathbf{0 . 0 3}$ & 9.89 & 0.42 & 0.03 & 15.20 \\
\hline CO-UN & -0.06 & 0.02 & -3.80 & -0.22 & 0.02 & -9.91 & -0.52 & 0.11 & -4.74 & -0.35 & $\mathbf{0 . 0 3}$ & -12.79 & -0.59 & 0.02 & -26.55 \\
\hline HO-UN & 0.02 & 0.02 & 0.99 & -0.01 & 0.02 & -0.52 & -0.32 & 0.11 & -3.00 & -0.09 & 0.03 & -3.20 & -0.17 & 0.02 & -7.15 \\
\hline $\begin{array}{l}\text { DS-RA } x \\
\text { HO-CO }\end{array}$ & -0.06 & 0.04 & -1.69 & -0.17 & 0.05 & -3.08 & -0.15 & 0.28 & -0.53 & -0.25 & 0.07 & -3.63 & -0.26 & 0.07 & -3.87 \\
\hline $\begin{array}{l}\text { DS-RA } x \\
\text { CO-UN }\end{array}$ & 0.03 & 0.04 & 0.84 & 0.21 & 0.05 & 3.89 & 0.63 & 0.28 & 2.27 & 0.45 & 0.07 & 6.64 & 0.50 & 0.05 & 9.02 \\
\hline $\begin{array}{l}\text { DS-RA } \times \\
\text { HO-UN }\end{array}$ & -0.03 & 0.04 & -0.86 & 0.05 & 0.05 & 0.83 & 0.49 & 0.27 & 1.81 & 0.20 & 0.07 & 3.04 & 0.23 & 0.06 & 4.02 \\
\hline $\begin{array}{l}\text { CA-DS } x \\
\text { HO-CO }\end{array}$ & 0.08 & 0.04 & 2.02 & 0.13 & 0.06 & 2.35 & 0.22 & 0.29 & 0.75 & 0.21 & 0.07 & 3.16 & 0.14 & 0.07 & 2.06 \\
\hline $\begin{array}{l}\text { CA-DS } \times \\
\text { CO-UN }\end{array}$ & -0.04 & 0.04 & -1.07 & -0.12 & 0.06 & -2.12 & -0.54 & 0.29 & -1.86 & -0.29 & 0.07 & -4.21 & -0.35 & 0.05 & -6.40 \\
\hline $\begin{array}{l}\text { CA-DS } \times \\
\text { HO-UN }\end{array}$ & 0.04 & 0.04 & 0.96 & 0.01 & 0.05 & 0.22 & -0.34 & 0.28 & -1.23 & -0.07 & 0.07 & -1.09 & -0.21 & 0.06 & -3.68 \\
\hline
\end{tabular}

Note: Model with group (RA, DS, CA), word type (correctly spelled words (CO), homophone words (HO), unrelated words $(\mathrm{UN})$ ) as fixed factors. Statistically-significant t-values are formatted in bold. 
Page 41 of 44

Scientific Studies of Reading

Running head: PHONOLOGICAL CODING IN CHINESE DEAF READERS

Table 5

Means and Standard Deviations for eye movement measures for the MSKD and LSKD groups.

\begin{tabular}{ccccccc}
\hline & \multicolumn{3}{c}{ MSKD } & \multicolumn{3}{c}{ LSKD } \\
\cline { 2 - 7 } & CO & HO & UN & CO & HO & UN \\
\hline FFD (ms) & $246(104)$ & $261(106)$ & $264(97)$ & $286(117)$ & $288(127)$ & $286(120)$ \\
GD (ms) & $279(164)$ & $336(199)$ & $370(216)$ & $389(221)$ & $421(248)$ & $389(228)$ \\
Regression out & $0.18(0.38)$ & $0.16(0.37)$ & $0.19(0.39)$ & $0.11(0.31)$ & $0.14(0.35)$ & $0.13(0.33)$ \\
RP (ms) & $392(316)$ & $461(379)$ & $492(377)$ & $464(301)$ & $526(365)$ & $484(348)$ \\
TT (ms) & $524(384)$ & $805(643)$ & $850(560)$ & $556(294)$ & $660(367)$ & $601(316)$ \\
\hline
\end{tabular}

Note: $\mathrm{CO}=$ correctly spelled words, $\mathrm{HO}=$ homophone words, $\mathrm{UN}=$ unrelated words

1

2

3

4

5

6

7

8

9

10

11

12

13

14 
Scientific Studies of Reading

Running head: PHONOLOGICAL CODING IN CHINESE DEAF READERS

\section{Table 6}

Results from LMMs for eye movement measures for the MSKD and LSKD groups.

\begin{tabular}{|c|c|c|c|c|c|c|c|c|c|c|c|c|c|c|c|}
\hline & \multicolumn{3}{|c|}{ First fixation duration } & \multicolumn{3}{|c|}{ Gaze duration } & \multicolumn{3}{|c|}{ Regression out } & \multicolumn{3}{|c|}{$\begin{array}{l}\text { Regression path } \\
\text { time }\end{array}$} & \multicolumn{3}{|c|}{ Total reading time } \\
\hline & $b$ & $S E$ & $t$ & $b$ & $S E$ & $t$ & $b$ & $S E$ & $z$ & $b$ & $S E$ & $t$ & $b$ & $S E$ & $t$ \\
\hline Inte & 5.56 & 0.06 & 99.89 & 5.79 & 0.08 & 72.91 & -2.16 & 0.34 & -6.33 & 5.97 & 0.10 & 61.06 & 6.25 & 0.10 & 62.83 \\
\hline Group & -0.07 & 0.08 & -0.89 & -0.06 & 0.11 & -0.50 & 0.55 & 0.45 & 1.22 & -0.02 & 0.14 & -0.17 & 0.29 & 0.14 & 2.10 \\
\hline Word type & 0.01 & 0.04 & 0.38 & 0.08 & 0.05 & 1.67 & 0.03 & 0.36 & 0.08 & 0.07 & 0.06 & 1.13 & 0.06 & 0.05 & 1.01 \\
\hline Interaction & -0.04 & 0.05 & -0.73 & -0.17 & $\mathbf{0 . 0 7}$ & -2.39 & -0.16 & 0.45 & -0.36 & -0.14 & 0.09 & -1.54 & -0.16 & 0.08 & -2.03 \\
\hline
\end{tabular}

Note: Model with group (MSKD, LSKD), word type (homophone words, unrelated words) as fixed factors. Statisticallysignificant $\mathrm{t}$-values are formatted in bold. 
Scientific Studies of Reading

Running head: PHONOLOGICAL CODING IN CHINESE DEAF READERS

\section{Figure Captions}

2 Figure 1. Gaze duration (panel a), regression path time (panel b), and total reading

3 time (panel c), on homophone words and unrelated words, for each of the four

4 participant groups.

5

6

7

8

9

10

11

12

13

14

15

16

17

18

19

20

21

22

23

24 
Scientific Studies of Reading

Running head: PHONOLOGICAL CODING IN CHINESE DEAF READERS

$1 \quad$ Figure 1

2 (a)

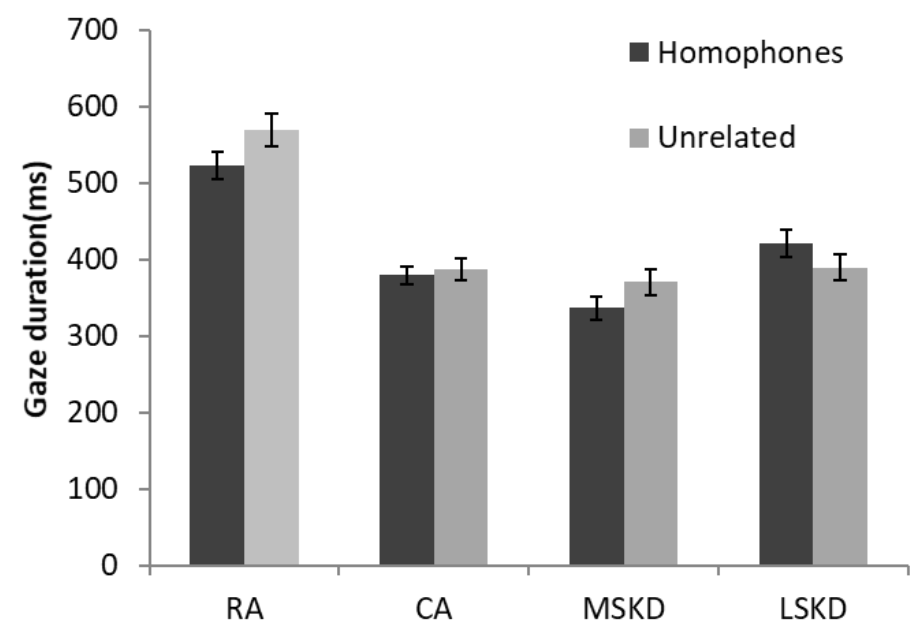

4 (b)

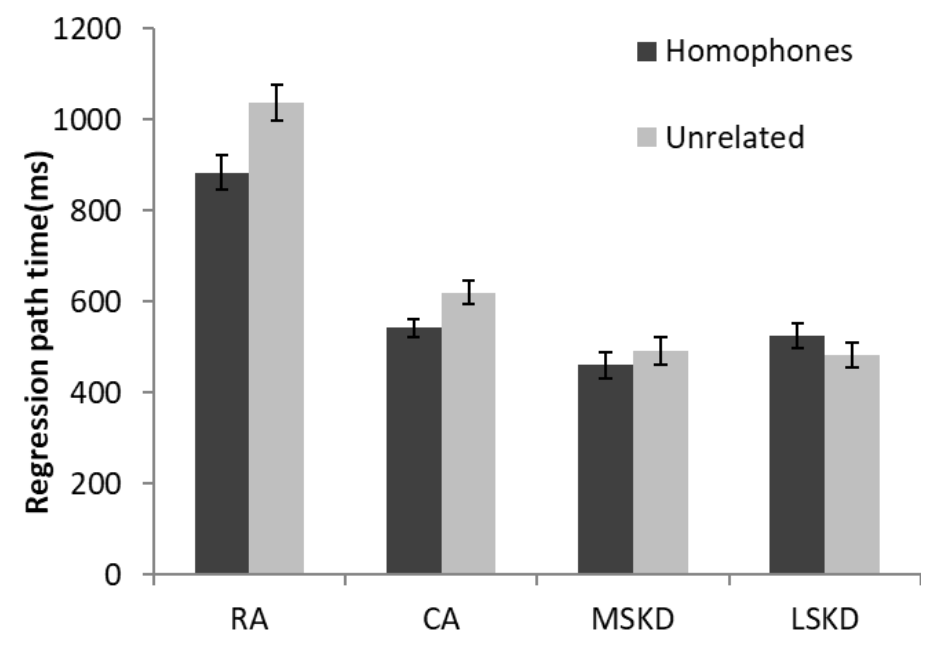

6 (c)

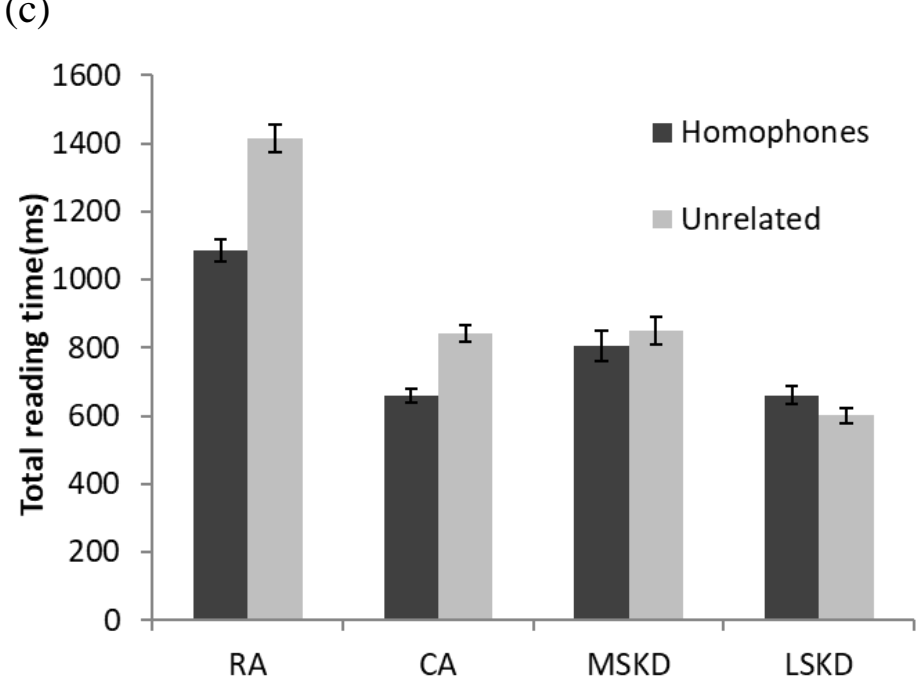

